\title{
In vitro SYNERGISM OF SIMVASTATIN AND FLUCONAZOLE AGAINST Candida SPECIES
}

Everardo Albuquerque MENEZES(1), Antônio Alexandre de VASCONCELOS JÚNIOR(1), Carlla Lorena Façanha SILVA(2), Fábio Ximenes PLUTARCO(1), Maria da Conceição dos Santos Oliveira CUNHA(1) \& Francisco Afrânio CUNHA(1)

\begin{abstract}
SUMMARY
Systemic fungal infections are responsible for high mortality rates. Several species of fungi may be involved, but Candida spp. is the most prevalent. Simvastatin is used to lower cholesterol and also exhibits antifungal action. The aim of this study was to evaluate the synergistic action of simvastatin with fluconazole against strains of Candida spp. Susceptibility testing was performed according to protocol M27-A3, by broth microdilution method and the synergistic effect of simvastatin and fluconazole was calculated based on FICI (Fractional Inhibitory Concentration Index). Eleven strains were evaluated, and simvastatin showed a synergistic effect with fluconazole against $10(91 \%)$ of the Candida spp. strains tested. Simvastatin may be a valuable drug in the treatment of systemic infections caused by Candida spp.
\end{abstract}

KEYWORDS: Simvastatin; Fluconazole; Candida spp.

\section{INTRODUCTION}

Candidemias are fungal infections that have high mortality rates and are responsible for increased hospital costs ${ }^{1}$. The number of available antifungal agents for systemic use is rather limited, and isolation of strains of Candida spp. resistant to conventional antifungal drugs is increasingly common ${ }^{4}$. New therapeutic strategies are needed to prevent the spread of resistance. Among these strategies we can highlight the search for new drugs and drug combinations with synergistic purpose ${ }^{3,9}$. Statins are drugs used to treat hypercholesterolemia, but also have antifungal activity ${ }^{6}$. Simvastatin inhibits the enzyme 3-hydroxy-3-methylglutaryl reductase (HMG-CoA) and reduces the level of intermediates from cholesterol synthesis. Yeasts use the same enzymatic pathway, but the final product is ergosterol. In vitro studies have demonstrated that simvastatin inhibits the growth of species of Candida spp. and may be useful in the treatment of candidemias $3,7,12$.

The aim of this study was to evaluate the synergistic action between simvastatin and fluconazole against Candida spp. with elevated MICs for fluconazole.

\section{MATERIALS AND METHODS}

In all, 11 strains of Candida spp. were used (one C. albicans, five C. tropicalis, and five $C$. parapsilosis). The strains used were derived from clinical samples (nine from blood and two from urine). The strains were identified by biochemical, molecular and phenotypic methods ${ }^{11}$.
In this study, we tested the antifungal activity of simvastatin alone and in combination with fluconazole. Simvastatin (Sigma-USA) was activated in an ethanol solution of $\mathrm{NaOH}(15 \%(\mathrm{vol} / \mathrm{vol})$ and $0.25 \%(\mathrm{~m} / \mathrm{vol}) \mathrm{NaOH})$ at $60{ }^{\circ} \mathrm{C}$ for one hour ${ }^{9}$. The simvastatin solution was filtered and placed in a desiccator for 72 hours. Susceptibility testing was performed according to protocol M27-A3, by the RPMI broth microdilution method (Cultilab-São Paulo) (pH 7.0) buffered with MOPS (morpholinepropanesulfonic acid) $\left(\right.$ Sigma-USA) ${ }^{2}$. Fluconazole (Sigma-USA) and simvastatin were dissolved in water and butanol (Sigma-USA), respectively. To assess the synergistic potential of the drugs, the concentration of fluconazole was maintained unchanged at $4 \mu \mathrm{g} / \mathrm{mL}$ and simvastatin ranged from 0.25 to $128 \mu \mathrm{g} / \mathrm{mL}$. The microdilution plates were incubated at $35^{\circ} \mathrm{C}$ and read visually after 24 hours and 48 hours of incubation. The MIC was considered as the lowest concentration of drugs that caused a $90 \%$ reduction in growth compared with the control strain. C. parapsilosis ATCC 22019 and C. krusei ATCC 6258 were used as control strains. The synergistic effect of simvastatin and fluconazole was calculated based on FICI (Fractional Inhibitory Concentration Index). The data were interpreted according to the value of FICI: FICI $\leq 0.5$-synergism (SYN); $0.5<$ FICI $<4.0$ - indifference (IND); and $\mathrm{FICI} \geq 4.0$ - antagonism $(\mathrm{ANT})^{10}$.

\section{RESULTS}

Table 1 shows the results of the FICIs ( $24 \mathrm{~h}$ and $48 \mathrm{~h}$ of incubation) for the strains tested. As can be verified, only one strain appeared as indifferent. In 10 strains, (91\%) there was a strong synergistic effect demonstrated by the FICI calculation. FICI determination at $24 \mathrm{~h}$

(1) Laboratory of Microbiology of Yeasts, Department of Clinical Analysis and Toxicology, College of Pharmacy, Federal University of Ceará, Brazil.

(2) Science Center, Course of Chemistry, Federal University of Ceará, Brazil.

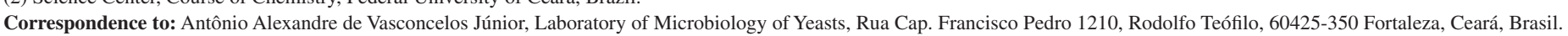
E-mail: alexandrevasconcelosjr@gmail.com. 
MENEZES, E.A.; VASCONCELOS JÚNIOR, A.A.; SILVA, C.L.F.; PLUTARCO, F.X.; CUNHA, M.C.S.O. \& CUNHA, F.A. - In vitro synergism of simvastatin and fluconazole against Candida species. Rev. Inst. Med. Trop. Sao Paulo, 54(4): 197-9, 2012.

Table 1

Synergistic effect of simvastatin and fluconazole against strains of Candida spp., with high MICs for fluconazole (24 and 48 hours of incubation), isolated in Ceará

\begin{tabular}{|c|c|c|c|c|c|}
\hline Strains $^{\mathrm{a}}$ & $\begin{array}{l}\text { Fluc }^{\mathrm{b}}(\mu \mathrm{g} / \mathrm{mL}) \\
\mathrm{MIC}_{90} 24 \mathrm{~h} / 48 \mathrm{~h} \\
\end{array}$ & $\begin{array}{c}\operatorname{Sim}(\mu \mathrm{g} / \mathrm{mL})^{\mathrm{b}} \\
\mathrm{MIC}_{90} 24 \mathrm{~h} / 48 \mathrm{~h} \\
\end{array}$ & $\begin{array}{c}\text { Fluc }^{c}(4 \mu \mathrm{g})+\operatorname{Sim} \\
\mathrm{MIC}_{90} 24 \mathrm{~h} / 48 \mathrm{~h}\end{array}$ & $\mathrm{FICI}^{\mathrm{d}} 24 \mathrm{~h} / 48 \mathrm{~h}$ & $\operatorname{Int}^{\mathrm{e}}$ \\
\hline C. albicans & 16 & $>128 />128$ & $<0.25 / 8$ & $0.25 / 0.31$ & SYN \\
\hline C. tropicalis & 16 & $64 />128$ & $<0.25 /<0.25$ & $0.25 / 0.25$ & SYN \\
\hline C. tropicalis & 8 & $64 />128$ & $<0.25 /<0.25$ & $0.50 / 0.50$ & SYN \\
\hline C. tropicalis ${ }^{u}$ & 8 & $>128 />128$ & $<0.25 /<0.25$ & $0.50 / 0.50$ & SYN \\
\hline C. tropicalis ${ }^{u}$ & 32 & $32 />128$ & $<0.25 /<0.25$ & $0.13 / 0.13$ & SYN \\
\hline C. tropicalis & 32 & $>128 />128$ & $<0.25 /<0.25$ & $0.13 / 0.13$ & SYN \\
\hline C. parapsilosis & 16 & $64 / 64$ & $<0.25 /<0.25$ & $0.25 / 0.25$ & SYN \\
\hline C. parapsilosis & 16 & $>128 />128$ & $<0.25 /<0.25$ & $0.25 / 0.25$ & SYN \\
\hline C. parapsilosis & 8 & $>128 />128$ & $<0.25 / 0.50$ & $0.50 / 0.5$ & SYN \\
\hline C. parapsilosis & 8 & $16 />128$ & $<0.25 / 16$ & $0.52 / 0.63$ & IND \\
\hline C. parapsilosis & 16 & $>128 />128$ & $<0.25 /<0.25$ & $0.25 / 0.25$ & SYN \\
\hline
\end{tabular}

${ }^{a}$ Yeast strains isolated from biological samples; $\mathrm{u}=$ urine, all other strains were isolated from blood.

${ }^{\mathrm{b}} \mathrm{Flu}$ - fluconazole (alone), Sim - simvastatin (alone). MIC was defined as the lowest concentration that produced $90 \%$ reduction in growth of fungal cells after 24 and 48 hours of incubation. The procedure was performed according to CLSI protocol M27-A3. The concentration of fluconazole ranged from 0.125 to $64 \mu / \mathrm{mL}$ and the concentration of simvastatin ranged from 0.25 to $128 \mu \mathrm{g} / \mathrm{mL}$.

${ }^{\mathrm{c}}$ The concentration of fluconazole was maintained unchanged at $(4 \mu \mathrm{g} / \mathrm{mL})$ and simvastatin ranged from 128 to $0.25 \mu \mathrm{g} / \mathrm{mL}$.

${ }^{\mathrm{d}}$ The synergistic effect of fluconazole and simvastatin was calculated based on the FICI (Fractional Inhibitory Concentration Index (FICI=[FC]/CFS+[SC]/CSS), where $[\mathrm{FC}]$ and $[\mathrm{SC}]$ are the concentrations of fluconazole and of simvastatin that showed action when combined, [CFS] and [CSS] are the concentrations of the same drugs acting alone.

${ }^{\mathrm{e}}$ The data were interpreted according to the FICI value. FICI $\leq 0.5$-synergism (SYN); $0.5<$ FICI $\leq 4.0$ - indifference (IND); and FICI $>4.0$ - antagonism (ANT).

might be better than longer incubation periods in detecting significant pharmacodynamic interactions ${ }^{8}$. In our study there was no difference in comparing the results with 24 and $48 \mathrm{~h}$ of incubation.

We observed that when simvastatin was associated with fluconazole at a fixed concentration $(4 \mu \mathrm{g} / \mathrm{mL})$, there was a reduction of the MICs. Several studies show the interaction of statins with antifungals ${ }^{5,9}$.

\section{DISCUSSION}

The FICI was $\leq 0.5$, thus proving the synergy. LIU et al. (2009) observed that simvastatin inhibits the formation biofilm in C. albicans. These same authors observed that the probable mechanism of this action is due to the interference in the ergosterol cycle. In our study, we did not elucidate the mechanism of action, but hypothesized that the mechanism of action is due to the action at two distinct points of the ergosterol cycle.

In a study conducted with strains of $C$. albicans and $C$. glabrata, evaluating the synergism between simvastatin and fluconazole, an additive effect was observed ${ }^{9}$. In our study, the results were different; we found a synergistic effect. This discrepancy may be due to the fact that the strains used in our study were strains with elevated MICs for fluconazole.

Studies have shown the usefulness of statins in the treatment of fungal infections; however, more studies are needed to confirm the synergism ${ }^{5}$.

In our study, we showed that simvastatin has in vitro synergistic activity with fluconazole against strains with elevated MICs for fluconazole. Simvastatin may be a valuable drug to the treatment of fungal infections mainly caused by strains of Candida spp. resistant to fluconazole. However, we know these are preliminary data and that the dosage and duration of treatment in humans should be carefully studied. Therefore, it is important that further studies, such as molecular studies and animal tests, be made. This is the first study with strains that have a degree of resistance. We also know that future studies with a larger number of isolates and resistant isolates are of great importance. Our studies will continue in order to elucidate the mechanism of action and effects of simvastatin.

\section{RESUMO}

\section{Sinergismo in vitro de sinvastatina e fluconazol contra espécies de Candida}

Infecções fúngicas sistêmicas são responsáveis por altas taxas de mortalidade. Várias espécies de fungos podem estar envolvidas, mas Candida spp é a mais prevalente. A sinvastatina é usada para diminuir o colesterol e também exibe ação antifúngica. O objetivo deste estudo foi avaliar a ação sinérgica de sinvastatina e fluconazol contra cepas de Candida spp. O teste de susceptibilidade foi realizado de acordo com o protocolo M27-A3, pelo método de micro diluição em caldo e o efeito sinérgico de sinvastatina e fluconazol foi calculado com base no ICIF (Índice de Concentração Inibitória Fraccionada). Onze cepas foram avaliadas, e a sinvastatina mostrou um efeito sinérgico com o fluconazol em dez (91\%) das cepas de Candida spp. Sinvastatina pode ser uma droga valiosa no tratamento de infecções sistêmicas causadas por Candida spp.

\section{ACKNOWLEDGEMENTS}

CNPQ. 


\section{REFERENCES}

1. Arendrup MC. Epidemiology of invasive candidiasis. Curr Opin Crit Care. 2010;16:44552.

2. Clinical and Laboratory Standards Institute. (CLSI). Reference method for broth dilution antifungal susceptibility testing of yeasts. Wayne: Clinical and Laboratory Standards Institute; 2008. Supplement M27-A3.

3. Forrest GN, Kopack AM, Perencevich EN. Research article statins in Candidemia: clinical outcomes from a matched cohort study. BMC Infect Dis. 2010;10:152-9.

4. Lass-Flörl C, Perkhofer S, Mayr A. In vitro susceptibility testing in fungi: a global perspective on a variety of methods. Mycoses. 2010;53:1-11

5. Lefebvre M, Alshawa K, Dupont B. L'activité antifongique des statines. J Mycol Med. 2010;20:212-7.

6. Liu G, Vellucci VF, Kyc S. Hostetter MK. Simvastatin inhibits Candida albicans biofilm in vitro. Pediat Res. 2009;66:600-4.

7. Macreadie IG, Johnson G, Schlosser T, Macreadie PI. Growth inhibition of Candida species and Aspergillus fumigatus by statins. FEMS Microbiol Lett. 2006;262:9-13.
8. Meletiadis J, Pournaras S, Roilides E, Walsh TJ. Defining fractional inhibitory concentration index cutoffs for additive interactions based on self-drug additive combinations, Monte Carlo simulation analysis, and in vitro-in vivo correlation data for antifungal drug combinations against Aspergillus fumigatus. Antimicrob Agents Chemother. 2010;54:602-9

9. Nyilasi I, Kocsubé S, Krizsán K, Galgóczy L, Pesti M, Papp T, et al. In vitro synergistic interactions of the effects of various statins and azoles against some clinically important fungi. FEMS Microbiol Lett. 2010;307:175-84.

10. Odds FC. Synergy, antagonism, and what the chequerboard puts between them. J Antimicrob Chemother. 2003;52:1

11. Vasconcelos Jr AA, Menezes EA, Cunha, FA. Chromogenic medium for direct susceptibility testing of Candida spp. isolated from urine. Mycopathologia. 2011;172:125-30

12. Wikhe K, Westermeyer C, Macreadie IG. Biological consequences of statins in Candida species and possible implications for human health. Biochem Soc Trans. 2007;35:1529-32.

Received: 23 March 2012

Accepted: 23 April 2012 


\section{LIBRARY OF THE SÃO PAULO INSTITUTE OF TROPICAL MEDICINE}

Website: www.imt.usp.br/portal

Address: Biblioteca do Instituto de Medicina Tropical de São Paulo da Universidade de São Paulo Av. Dr. Enéas de Carvalho Aguiar, 470. Prédio 1 - Andar térreo.

05403-000 São Paulo, SP, Brazil.

Telephone: 5511 3061-7003 - Fax: 5511 3062-2174

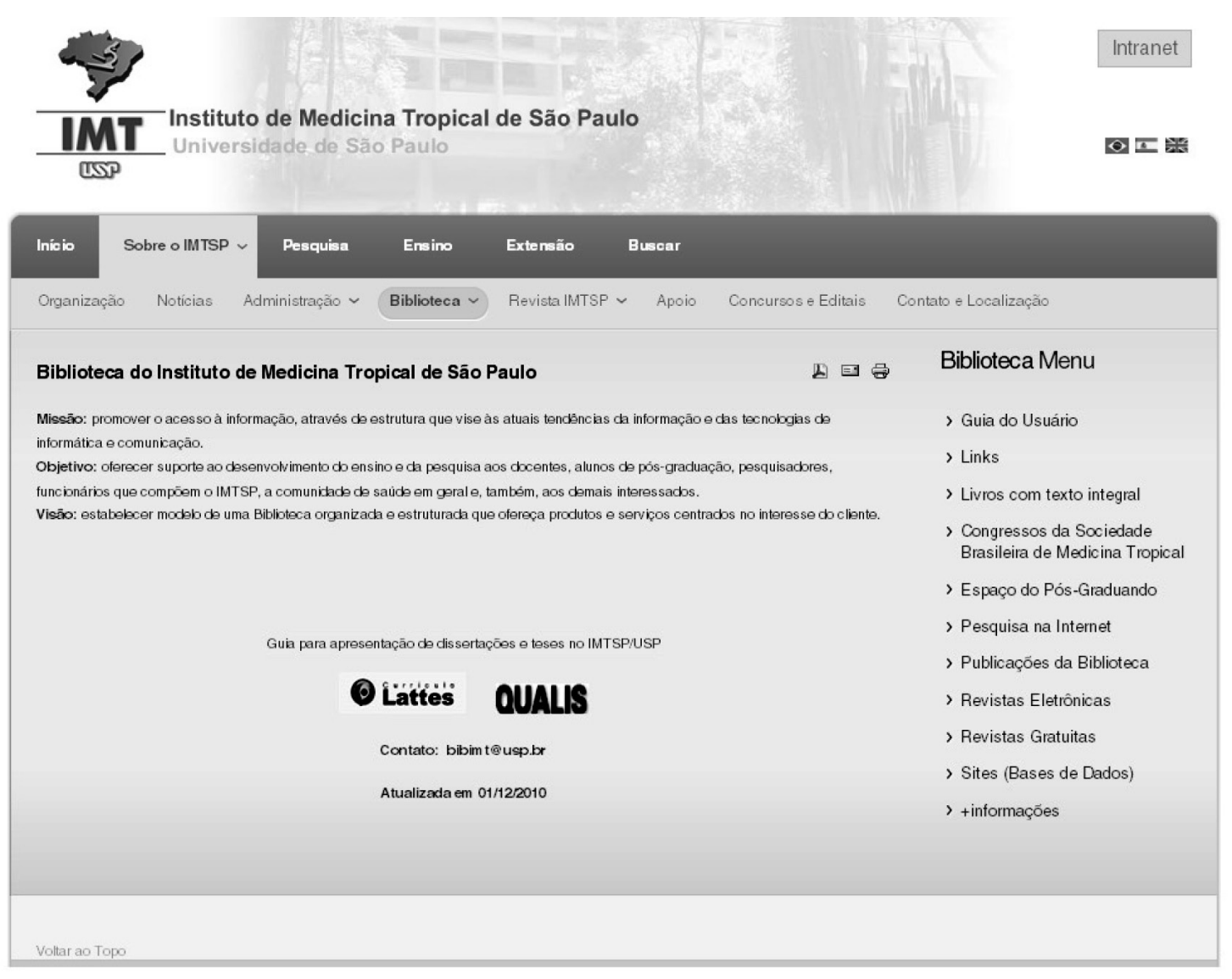

The Library of the São Paulo Institute of Tropical Medicine (IMTSP Library) was created on January 15,1959 in order to serve all those who are interested in tropical diseases. To reach this objective, we select and acquire by donation and / or exchange appropriate material to be used by researchers and we maintain interchange between Institutions thorough the Journal of the São Paulo Institute of Tropical Medicine, since the Library has no funds to build its own patrimony.

The IMTSP Library has a patrimony consisting of books, theses, annals of congresses, journals, and reference works.

The collection fo journals existing in the Library can be verified through the USP - Bibliographic Database - OPAC - DEDALUS http://dedalus.usp.br:4500/ALEPH/eng/USP/USP/DEDALUS/start of the USP network. 